\title{
«Я противник режима, но всегда работаю на "Единую Россию"», или о политтехнологическом сообществе в современной России
}

\author{
Н.В. КОЛЕСНИК*
}

\begin{abstract}
*Наталья Владимировна Колесник - кандидат социологических наук, ученый секретарь, старший научный сотрудник, сектор социологии власти и гражданского общества, Социологический институт РАН - филиал ФНИСЦ РАН. Адрес: Санкт-Петербург, 7-я Красноармейская ул., д. 25/14. E-mail: n.kolesnik@socinst.ru
\end{abstract}

Цитирование: Колесник Н.В. (2021) «Я противник режима, но всегда работаю на "Единую Россию"», или о политтехнологическом сообществе в современной России // Мир России. Т. 30. № 4. С. 79-105. DOI: 10.17323/1811-038X-2021-30-4-79-105

В работе рассматривается проиесс институичионализации рынка политических услуг на примере функиионирования политтехнологического сообщества. В начале работы уделяется внимание академическим дискуссиям по поводу связи авторитарных режимов и выборов. Среди важных характеристик «электоральных автократий» были выделены следуюшие: наличие многопартийной системы, регулярные парламентские выборы, всеобщее избирательное право и другие составляюшие «демократического ландшафта». Основной предмет эмпирического исследования состоит в прояснении роли политтехнологов в структуре избирательных кампаний, анализе формальных и неформальных аспектов избирательных кампаний в российских регионах. Работа состоит из нескольких основных частей: история формирования рынка политических профессий в современной России, источники рекрутирования и социально-экономический статус политтехнологов, особенности профессиональных траекторий после завершения карьеры политтехнолога. Эмпирической основой для исследования послужили 76 глубинньх полуформализованных интервью с основными агентами избирательного прочесса в российских регионах (политическими технологами, журналистами, представителями региональных администраций, партийньми активистами, владельцами консалтинговых компаний и др.). Анализ полученных данных показывает, что процесс формирования политтехнологического

1 Статья опубликована в рамках проекта НИУ ВШЭ по поддержке публикаций авторов российских образовательных и научных организаций «Университетское партнерство». 
сообщества в современной России носит незавериенный характер, избирательные кампании представляют собой двуединый процесс, когда гранищь между политическим бизнесом и политическим процессом стираются, и главным становится не качество предоставляемых услуг, а длительность самого процесса.

Ключевые слова: избирательная кампания, выборы, политтехнологи, рынок, российский регион, власть, ресурсы

\section{Введение}

В последние десятилетия изучение политических режимов, выборов и избирательных кампаний становится заметным исследовательским направлением в зарубежной и российской науках. Среди ученых развернулись активные дискуссии по поводу того, какую роль играют выборы в авторитарных политических режимах. Для описания трансформационных процессов в странах «новой демократии» в научном дискурсе стали использоваться концепты «авторитаризм» и «электоральные автократии». В качестве важных характеристик «электоральных автократий» исследователи определили наличие многопартийной системы, регулярные парламентские выборы и всеобщее избирательное право.

Важной составляющей «демократического ландшафта» в современной России являются множественные субъекты федеральных и региональных избирательных кампаний. Чаще всего в исследованиях избирательных кампаний основной исследовательский фокус смещен на анализ формальных и неформальных практик кандидатов и избирателей, бизнеса и власти. На этом фоне практически не исследованными остаются политтехнологи как социальное сообщество, представители которого активно участвуют в избирательных кампаниях, извлекают максимальную выгоду и пользу, минимизируя свои издержки и неопределенности. В этой связи обозначенные практики порождают череду исследовательских вопросов, которые требуют своего прояснения.

На основе эмпирического исследования избирательных кампаний в российских городах автором предпринимается попытка показать основные субъекты региональных выборов, формальные и неформальные практики избирательного процесса, этапы формирования рынка политических профессий в современной России, профессиональный статус политтехнологов и особенности профессиональных траекторий после завершения карьеры.

\section{Выборы и избирательный процесс как проблема исследования}

Одно из важных исследовательских направлений при обсуждении избирательных кампаний связано с механизмом функционирования выборов в условиях различных политических режимов. Если в странах устойчивых демократий выборный процесс является легитимной процедурой воспроизводства власти без нарушения принципов демократической конкуренции, то в других политических условиях вы- 
боры подчинены закону «соревновательного» или «электорального» авторитаризма $^{2}$. Исследователи авторитарных режимов ${ }^{3}$ часто обращают внимание на то, что государство в условиях автократий оказывается главным агентом по превращению электоральной системы в закрытую и непрозрачную, несмотря на то, что электорат осуществляет выбор в стране с многопартийной системой [Schedler 2006; Levitsky, Way 2010; Way 2005].

Автократический политический порядок предполагает, что со стороны политической элиты определяются заведомо неравные правила для «своих» и «чужих», когда риски по крушению авторитарных режимов практически сведены к нулю. В исследовании Д. Ганди по авторитарным режимам, существовавшим в период с 1946 по 2002 г., показано, что если в условиях либеральных демократий выборы как институт являются эффективным инструментом смены власти, то при авторитаризме этого не происходит [Gandhi 2008]. Для того чтобы сохранить власть и избежать внешних и внутренних угроз, правители вынуждены формировать контролируемые политические институты.

Б. Магалони в своих исследованиях определяет выборы как способ сохранения и выживания авторитарных правителей, однако и в условиях контролируемых выборов всегда имеются риски, связанные с потерей власти. Поэтому управляемые от имени правителя выборы в национальные парламенты оказываются надежным гарантом для удержания не только собственной власти, но и кооптации в депутаты новых «служилых» политиков. Неслучайно для описания подобных явлений Б. Магалони использует понятие «авторитарное мошенничество», когда результаты выборов оказываются одним из пунктов контракта, заключенного между диктатором и властными элитами. Используя преимущества многопартийной системы, диктатор тем самым создает основу для взаимовыгодных сделок (институциональные выгоды) между всеми участниками процесса, включая и оппозицию. По мнению Б. Магалони, в соревновательных автократиях фальсификации в ходе избирательного процесса являются рядовым и обычным делом. «Способность контролировать электоральный процесс на местах любыми средствами, достигнутая подчас в ущерб эффективности управления, обусловила новый неформальный контракт по схеме «монопольное сохранение власти в обмен на “правильные” результаты голосования» [Magaloni 2010].

Другое важное исследовательское направление при изучении выборов и избирательных кампаний связано с экономической оптикой, когда выявляется влияние макроэкономических показателей на политическое развитие различных государств, определяются взаимосвязь экономики и избирательного процесса, влияние политического режима на экономическую идеологию [Alesina, Roubini, Cohen 1997; Nordhaus 1975]. Согласно теории У. Нордхауза, существует прямая зависимость между фискальной политикой национального правительства и предвыборными циклами [Nordhaus 1975]. Росту популярности правительства способствует не только гибкая фискальная политика накануне выборов, но и эффективная кредитно-денежная политика. Не всегда в странах со стабильными демократиями

\footnotetext{
2 В первую очередь различие состоит в том, что в соревновательных автократиях выборы являются основным средством обретения политической власти при сохранении регулярных процедурных нарушений.

3 А. Шендлер определяет электоральный авторитаризм как тип политического режима, при котором существуют институты представительной демократии, но выборы являются объектом манипуляций со стороны государства.
} 
экономические и социальные трансформации оказывают влияние на поведение избирателя и итоги голосования. Если в случае голосования американского избирателя важным оказывается его доход, то на результаты избирательных кампаний в европейских странах влияет такой структурный фактор, как уровень безработицы.

Представляют исследовательский интерес те работы, в которых анализируются электоральные процессы в посткоммунистических странах, и то, какое влияние на эти процессы оказывает новая экономическая политика. По справедливому замечанию В. Мау, О. Кочеткова и С. Жаворонкова, это касается как стран, чья экономическая политика отличалась стабильностью и обеспечивала неуклонное продвижение вперед (Польша, Венгрия, Чехия, Эстония), так и тех, чья политика была подвержена сильным колебаниям от жесткой стабилизации к откровенному левому популизму (Болгария, Румыния, Россия, Украина) [Мау, Кочетков, Жаворонков 2019]. В этих работах исследователи оперируют большими массивами данных, которые позволяют описывать российские избирательные практики при помощи математического языка и большой статистики. Как правило, в фокусе внимания российских исследователей электоральных процессов оказываются макроэкономические показатели и количественные данные [Попова 2011; Попова 2012; Голосов 1999; Хлопин 1997].

Отдельный пул составляют работы, в которых избирательный процесс в современной России подвергается детальной и тщательной операционализации с позиций микроанализа либо использования методики кейс-анализа, когда анализируются, в терминологии М. Люиса-Бека, индивидуальные модели. Так, в работах С.Ю. Барсуковой, Е.В. Денисовой-Шмидт, В.И. Звягинцева, С.Н. Левина и других на примере региональных избирательных кампаний рассматриваются не только пассивные и активные инвестиции российского бизнеса в выборный процесс, но и соотношение административного и финансового ресурсов как условий победы на выборах, степени подконтрольности и автономии российских предпринимателей в их электоральной активности [Барсукова, Денисова-Шмидт 2020; Барсукова, Звягинцев 2006]. Особый интерес для исследования политтехнологического сообщества представляют модели организации и проведения избирательных кампаний в региональной России на основе соотношения административного и финансового ресурсов: жесткая, мягкая и конфликтная модели [Барсукова, Левин 2020].

Еще одно важное направление в исследовании российских выборов связано с тем, что развернувшиеся политические процессы оказали заметное влияние на трансформацию рынка профессий. Открытие российской политики, хронологически совпадающее с приходом к власти Б.Н. Ельцина, привнесло в повседневный обиход не только комплекс новых политических инструментов и политический тезаурус, но и новый субъект политики - политтехнолога. После перестройки политтехнологи/консультанты становятся важным элементом федерального и регионального политического рынка в России и оказываются достаточно востребованными. По словам К. Киселева, «консультант в это время был шаманом, он знал тайну победы, он умел все, он изрекал пророчества, он осознавал свою важность и незаменимость. В это время политические консультанты начинают воспринимать себя как субъектов политического процесса, появляется расхожее мнение о том, что побеждает не политик, не клиент, а консультант» [Киселев 2002].

На фоне других посткоммунистических стран российская электоральная машина часто видится как вполне эффективно функционирующий элемент политического рынка. Элиты как главные субъекты активно используют админи- 
стративные и экономические ресурсы для поддержания формы демократических институтов не только в период избирательных кампаний, но и между ними. Для воспроизводства электоральной автократии государству необходима значительная консолидация как формальных, так и неформальных ресурсов. Опорой этого режима оказываются те структуры и институции, которые напрямую зависят от государства или существуют на бюджетные средства, начиная от образовательных и медицинских учреждений, СМИ и заканчивая силовыми учреждениями. В этой связи пул провластных политтехнологов и тех, кто активно рекрутирован в многочисленные избирательные кампании по всей стране, видятся нам как значимый элемент в воспроизводстве автократического электорального режима.

Таким образом, рассмотренные исследовательские сюжеты и направления определили проблему и структуру исследования. В данной статье на основе первичных данных выявляется роль политтехнологов в региональных избирательных кампаниях в современной России, реконструируются история и источники формирования данного профессионального сообщества, анализируются формальные и неформальные практики региональных избирательных кампаний. Особое внимание уделено тем изменениям, которые произошли внутри профессионального сообщества политтехнологов на протяжении последних 30 лет.

Эмпирическую базу исследования составили глубинные полуформализованные интервью (всего 76 интервью) с основными агентами избирательного процесса в российских регионах (от политического технолога до представителя региональной администрации), которые были собраны в 2019-2020 гг. в Санкт-Петербурге, Москве, Кемерове, Ульяновске, Новосибирске, Бердске, Красноярске, Екатеринбурге ${ }^{4}$. В гайд интервью был включен не только биографический блок, но и вопросы о формальных и неформальных практиках избирательных кампаний в российских регионах. Подбор информантов осуществлялся посредством метода «снежного кома», поскольку при обсуждении проблемы неформальных аспектов избирательных кампаний он оказывается крайне эффективным, позволяя отсекать случайных информантов, тех, кто мало осведомлен или вообще не принимал участие ни в одной избирательной кампании 5 . В большинстве случаев были проинтервьюированы политтехнологи, журналисты, представители региональной элиты, вузовские преподаватели, научные сотрудники, которые работали в избирательных штабах по выборам президента России, «Единой России», ЛДПР, КПРФ. Опрашивались и партийные активисты российской оппозиционной партии, которые отмечали, что для тех, кто баллотировался в региональные парламенты в 2016 г., услуги внешних политтехнологов оказались практически не доступными ввиду отсутствия финансовых ресурсов ${ }^{6}$.

\footnotetext{
4 Выражаю огромную благодарность моим коллегам, которые любезно предоставили для анализа интервью с московскими, кемеровскими и ульяновскими информантами.

5 В среднем интервью длилось около 90 минут, проводилось как в офлайн-, так и в онлайн-формате.

6 Это неизбежно привело к тому, что баллотирующийся кандидат осуществлял избирательную кампанию самостоятельно. Для тех же кандидатов, которые заведомо были непроходными, экономия на услугах политтехнологов была для предвыборного штаба партии осознанной и являлась важной составляющей их предвыборной тактики. При этом известны случаи, когда кандидаты успешно баллотировались в региональные парламенты от оппозиционной партии, вообще не прибегая к услугам политтехнологов.
} 


\section{Результаты исследования «Пускали тогда свободно и легко», или о первых российских политтехнологах}

Впервые в российской политике политтехнологи появились в начале 1990-х гг., и с конца прошлого века федеральные, региональные избирательные кампании без их участия практически не обходятся. Экспертные мнения относительно того, когда и где впервые появилась фигура политтехнолога в постсоветской России, не сильно различаются. По некоторым данным, это произошло в 1996 г., когда «Новая газета» опубликовала статью, посвященную членам избирательного штаба Б.Н. Ельцина. По другим данным, впервые термин «политические технологии» встречается в 1990 г. в названии Института социальных и политических технологий. Третьи определяют февраль 1992 г. в качестве отправной точки, когда Г.Э. Бурбулис создал Международный гуманитарный и политологический центр «Стратегия», целью которого было содействие развитию и углублению реформ в России.

В Санкт-Петербурге, по мнению информантов, политтехнологи появились еще в 1980-е гг., когда проходили первые выборы в стране. В роли политтехнологов выступали комсомольские работники, журналисты, лидеры «Народного фронта» и волонтеры. Среди политтехнологов часто встречалась и такая категория, как «общественники», - молодые люди, которые начали заниматься общественно-политической деятельностью еще со школьной скамьи, организовывая молодежные слеты, конференции и конкурсы.

«До того, как заниматься избирательными кампаниями, я долгое время занимался общественной молодежной и потом молодежно-политической деятельностью. То есть до первой кампании я был в движении “Наши”, а до этого у меня была молодежная общественная организация аж с 18 лет, потому что по законодательству Российской Федерации общественные организации можно создавать с 18-летнего возраста. И до этого еще я в школе занимался развитием школьного самоуправления. То есть общественной деятельностью я начал заниматься лет с 15. И получается, первая кампания у меня была в 21 год. Ну вот, считайте, 6 лет до этого я уже чемто таким неординарным, нерабочим занимался. В “Наших" я занимался молодежнополитической деятельностью, при том что за это не получал ни рубля. Потом, когда меня позвали на избирательную кампанию и начали платить солидные деньги за то же самое, чем я занимался у “Наших”, мне это очень понравилось» (интервью № 63).

Понятные и простые отношения между людьми в СССР, по мнению информантов, накладывали отпечаток и на восприятие первых незатейливых политических технологий. В тот период популярной была технология «поквартирного обхода», когда кандидат в депутаты лично знакомился в ходе обхода избирательного участка со своими потенциальными избирателями. 
выборы в Ленсовет, знаменитые первые демократические выборы. Собственно, в этом мы и участвовали на разных уровнях, были выборы на уровне районном, тогда была простая технология, ходишь по квартирам и беседуешь с людьми. Пускали тогда свободно и легко, это было неожиданно, люди были морально не готовы к тому, что к ним будут заходить. Пускали всех легко и свободно» (интервью № 63).

Прежние провластные структуры (в т. ч. партийные и профсоюзные) практически не оставляли возможностей для обсуждения на своих площадках альтернативных точек зрения. Парадокс ситуации заключался в том, что представители партийных областных структур (КПСС) часто становились инициаторами создания альтернативных политических движений: в Санкт-Петербурге, например, в то время были созданы «Народный фронт» и «Объединенный фронт трудящихся».

\begin{abstract}
«Вбросить идею через эти (партийные и комсомольские - прим. автора) структуры, и чтобы она работала, было уже тогда невозможно, они воспринимались как структуры предыдущего времени, и попытка обсуждать новые темы через них была нереальна. Чтобы обсуждать новые темы, необходимо было, чтобы появились новые институты и новые СМИ» (интервью № 1).
\end{abstract}

Одновременно с технологиями поквартирного опроса в орбиту выборов вовлекались и практики по использованию в избирательных кампаниях медийных возможностей советских и постсоветских СМИ. На этом фоне новые постсоветские медиа позволяли транслировать кандидатам в депутаты всех уровней, лидерам общественного мнения иную точку зрению на политические и экономические процессы, тем самым подрывая старые смыслы и тональности официальных структур.

«В начале 1990-х - коние 1980-г2. появилась масса совершенно новых газет, которые читались как некое открытие: "Новый мир”, “Литератор”, “Вестник народного фронта”, “Мегаполис-экспресс”. Тогда же появился и “Час пик”» (интервью № 1).

В результате развернувшихся после перестройки процессов профессия политтехнолога/консультанта ${ }^{7}$ становится важным элементом политического рынка в России. В 1990-е гг. рынок политических услуг (РПУ) в стране рос достаточно стремительно: не только в мегаполисах, но и на региональном уровне компании политического консалтинга активно боролись за место под солнцем. По мнению экспертов, в те годы региональные компании, обслуживающие избирательные кампании, часто по своему профессиональному потенциалу были даже сильнее, чем столичные «варяги». Период с конца 1990-х и до начала 2000-х гг. эксперты определяют как второй этап в процессе становления профессии политтехнолога.

7 В данной статье термины «политтехнолог» и «политконсультант» используются как синонимы. 
Эти годы характеризуются бурным ростом политических технологий, когда политтехнологи, не скованные законами, профессиональной этикой и кодексом чести, вытеснили с политической арены публичную политику. К 2002 г. закончился этап «первоначального накопления профессионального капитала» технологов в политике, поскольку в российскую законодательную практику были введены ограничения по применению определенных политтехнологий; правовому регулированию подверглась и профессиональная деятельность политтехнологов.

В начале 2000-х гг. произошел очередной этап реформирования политической сферы, когда были отменены выборы губернаторов и выборы по одномандатным округам в российский парламент. Эти законодательные меры оказали заметное влияние на рынок политических услуг ввиду того, что выборы губернаторов и кандидатов-одномандатников были одними из самых затратных мероприятий. Введенная пропорциональная система резко сократила объемы заказов на региональных РПУ: по данным экспертов, региональные рынки сжались примерно в 3-5 раз. Именно с 2003-2004 гг. и начался активный процесс сращивания РПУ с административной властью. Региональная власть в лице административной и политической элиты стала активно выступать в роли основных заказчиков. Объемы заказов, получаемых компаниями политического консалтинга, оказывались пропорциональны близости той или иной компании к властным структурам. Что касается политтехнологов-одиночек, то многие из них в этот период были рекрутированы на высокие позиции в региональные структуры власти.

С конца 1990-х гг. практически все избирательные кампании в России проходили с участием политтехнологов, но при этом ни одно образовательное учреждение в те годы профессионально не осуществляло подготовку специалистов по политическим профессиям. В российской образовательной и политической системе сложилась парадоксальная ситуация: не был принят ни один профессиональный стандарт в сфере политических профессий (соответствующие профессии не были включены в справочник профессий Министерства труда и социального развития $\mathrm{P}^{8}$ ). Таким образом, отсутствие политического рынка в западном понимании не способствовало специальной подготовке кадров. Неслучайно в политические профессии в конце 1980-х и в начале 1990-х гг. активно приходили журналисты, вузовские преподаватели, бывшие комсомольские и партийные работники (комсорги и парторги), студенты и даже безработные. Верно подметил Алекс Джей Бакстер: «Любому журналисту, любому студенту достаточно один раз поучаствовать в коммерческой или политической кампании и посмотреть на шефов (которые его наняли), чтобы сказать: “И я так могу!”» [Гусев и др. 2002, с. 10-11].

Что же касается подготовки ключевых специалистов для политического рынка, а именно политтехнологов, то она «оказалась по большей части вне системы подготовки специалистов-политологов. Профиль “политический менеджмент" начал институционально оформляться лишь в 2000-х гг., специалисты по медиапланированию готовились по специальности "реклама", спичрайтерами и специалистами по СМИ становились журналисты, а юристы и психологи готовились на соответствующих факультетах вне привязки к политической проблематике» [Морозов и др. 2017, с. 13].

\footnotetext{
8 https://spravochnik.rosmintrud.ru/professions
} 
Данные интервью демонстрируют, что в начале перестройки функцию по подготовке и обучению специалистов для проведения избирательных и политических кампаний часто брали на себя иностранные специалисты. В те годы зарубежные организации в целях развития демократических институтов в странах Восточной Европы организовывали стажировки для начинающих молодых политтехнологов и разрабатывали специальные образовательные программы. Например, некоторые известные региональные политтехнологи Санкт-Петербурга смогли повысить свою квалификацию в рамках программы «Америка 500» в 1993-1994 гг., когда им удалось пройти обучение в США. Подобные стажировки в Санкт-Петербурге были организованы для региональных молодых политтехнологов благодаря связям представителей местного бизнеса и американского консула.

«Американка, которая все это создала, хотела помочь, научить российских женщин правильно вести избирательные кампании, чтобы они могли избираться. Она здраво рассуждала. Б. плотно общался с американским консулом, который ее поддерживал. В какой-то день мы приходим в офис. "Пойдемте, у меня американка, и она хочет помогать женщинам”. И мы тут же начали общаться, она решительная дама и сразу же говорит: “Давай их (нас - прим. автора) на стажировку”. Они быстро договорились, он заплатил за билеты, она оплатила за наме пребывание там. У нас была шестинедельная поездка, т. е. вот так все это начиналось. Поездка состоялась после того, как мы работали на выборах в 1993 г. в Госдуму» (интервью № 6).

Организаторы специальной программы «Открытый мир» в 1990-е гг. предоставляли возможность пройти стажировку в США не только столичным, но и региональным политтехнологам. Программа позволяла начинающим политтехнологам получить теоретические и практические знания в области избирательных технологий. Многие из тех, кто ездил в США, могли наблюдать за предвыборной гонкой кандидатов на президентский пост и знакомиться с американскими избирательными практиками.

«Ой, а я, кстати, когда-то ездил в Штаты по программе “Открытый мир”, когда ее еще не запретили, был в городе Колорадо-Спрингс. Свинья же везде грязь найдет: я там умудрился поучаствовать в избирательных мероприятиях Хиллари Клинтон против Барака Обамьл. То есть был внутрипартийный у них праймериз, я тогда жил в семье. Слушайте, я вам скажу: у них все даже более покупается, чем у нас, только оно очень грамотно юридически простроено. Как сказал коллега оттуда: “Наша демократия - это хорошо отрегулированный блат”. И это правда. То есть вот, пожалуйста, чаепитие с ветеранами вветнамской войны, все оплачивается фондом, юристы все это правильно оформили. То есть у нас чаепитие, пирожки, всякие прочие прелести - это подкуп избирателей; у них - нет, у них все юридически оформлено. Молодизы» (интервью № 72).

Специальным образованием российских политтехнологов в 1990-е гг. зарубежные гуру избирательных кампаний активно занимались и в самой России. 
Для этих целей зарубежные профессионалы также разрабатывали образовательные программы: так, в середине 1990-х гг. была организована серия семинаров для региональных политтехнологов, которые проходили в подмосковном Голицыно. Один из участников семинара вспоминает:

«В начале года у нас работали американць-демократы, Национально-демократический институт международных отношений. У них там два института при партиях, вот этот НДИ и Республиканский международный институт. Так они тогда по очереди получали деньги для финансирования проектов в странах начинающихся демократий. Ну и, соответственно, когда президент-демократ, деньги есть у демократов, и наоборот. В то время был Клинтон, соответственно, тут НДИ проводил семинар. В Петербурге они не проводили. У них под Москвой, в Голищыно, была серия семинаров. Они собирали гайдаровскую партию и “Яблоко". По-моему, еще там ктото был, зеленье какие-то, дальше по мелочи» (интервью № 6).

Начиная с 2000-х гг. образовательные зарубежные программы для российских политтехнологов попадали под запрет, и в стране стали формироваться новые общественные институции, которые взяли на себя образовательную функцию в области политики. Многочисленные конкурсы, форумы и программы, начиная от «Лидера России», позволяли не только политтехнологам, но и будущим политикам постигать азы управления и ведения избирательных кампаний.

«Под видом “Лидер России” < ..> вот через такие институты я получил большой опыт, через знакомство с теми, кто имел богатые практические знания, ну и собственный практический опыт. В 2004 г. мы работали на нового губернатора. Мы были отобраны по разным конкурсам и хотели продемонстрировать, что на фоне административного ресурса, который был в руках прежнего губернатора, новые технологии позволяют этот заслон преодолеть. Так и получилось» (интервью № 72).

В целом, несмотря на то, что в разные годы существовали образовательные площадки для политтехнологов, анализ биографий показывает, что большинство из них не имели специального профессионального образования. Исключение составляли политические юристы, без которых не обходилась ни одна избирательная кампания.

«Единственные, у кого имеется сопряженное профильное образование, - это политические юристы, которые оканчивали юридические факультеты. Все остальные: креаторы, полевики, райтеры. < ..> Ну, райтеры, может быть, журфаки окончили, ok. А вот из нашего цеха, мне кажется, с профильным образованием никого не найдешь» (интервью № 63). 
При этом, как замечали в интервью сами юристы, ни в одном российском вузе не осуществляется подготовка юристов по избирательному праву, но специализация по конституционному праву вполне позволяет разбираться и с выборными вопросами.

«Избирательное право у нас считается подотраслью конституциионого, вот права и вот конституционное право, это тоже достаточно редкая спеииализация. В эпоху разгула формальных дипломов с высшим образованием, когда люди получают высшее образование и очень часто по нему не работают, я работаю не просто по специальности юристом, я работаю по специиализации. Моя специиализация - как раз конституционное право. Я кандидат юридических наук, диссертацию я защцичала именно по специиализации - конституционное, муниципальное (право - прим. автора)» (интервью № 46).

Анализ данных продемонстрировал, что как в прошлом, так и сейчас профессиональное образование не является для политтехнолога главным пропуском на рынок политических услуг. По-прежнему ни один российский вуз не осуществляет профессиональной подготовки политических технологов и политических консультантов для российской политической системы ${ }^{9}$. При этом следует отметить, что представители политтехнологического сообщества, даже не имея специального образования, в целом представляют собой высокообразованную общность. Как правило, те, кто пришел в эту профессию в 1990-е гг. и позже, имеют вузовские дипломы историков, философов, экономистов, журналистов и юристов.

Полученные данные позволили заключить, что в своем развитии политтехнологическое сообщество в современной России прошло несколько этапов развития - от «золотого времени», относительно свободного для реализации профессиональных интересов, до полной монополизации политического рынка со стороны государства. В течение последних 20 лет монополизация государства в политической и экономической сфере привела к тому, что с политического рынка ушли не только политтехнологи-одиночки, но и консалтинговые компании мелкого и среднего уровня. Основная часть российских политтехнологов работает в социальных сетях, проводя свою аналитику и вступая лишь в виртуальные диалоги с федеральной властью. По словам политтехнолога В. Смирнова, «мы застоялись, и хочется поспекулировать перед администрацией президента. Тем более что самое обидное, что ответной реакции мы не слышим. Мы много говорим, много пишем в Фейсбуке, мы как бы вызываем на диалог, а там даже не ау» ${ }^{10}$. В настоящее время сформирован пул уполномоченных политтехнологов, который получает напрямую крупные заказы от федеральной власти, и, как в случае с экономическими компаниями, случайных подрядчиков там не бывает.

\footnotetext{
9 Исключение составляют кратковременные программы/семинары по подготовке политконсультантов и юристов по сопровождению избирательных кампаний в российских вузах.

10 «Денег не дают, методичек не дают». Политтехнологам не хватает взаимодействия с администрацией президента (2017) // Коммерсантъ. 31 марта 2017 // https://www.kommersant.ru/doc/3256983
} 


\title{
Профессиональные траектории и иерархии в политтехнологическом сообществе
}

В конце 1990-х гг. политтехнологическая общность в России только зарождалась, и поэтому видится закономерным, что в условиях кадрового вакуума довольно часто в нее рекрутировались партийные и комсомольские активисты (как и в первые экономические структуры в эпоху перестройки). В тот период формировались новые общественные и политические институции, которые становились площадкой для отработки первых избирательных технологий. Одной из таких институций стала «Сургутская альтернатива» - как альтернативное движение советскому комсомолу. По мнению бывшего секретаря комсомольской организации одного из петербургских вузов, 1980-1990-е гг. были временем, когда предпринимались активные попытки изменить структуру комсомола:

\begin{abstract}
«Понятно, что комсомол был тогда более-менее большой молодежной организаиией, которая объединяла в себя совершенно различных людей, идеологии, направления деятельности. Вообще-то идея была создать из ВЛКСМ массовое движение, объединяющее различные структуры. Политические ориентации (внутри комсомола) были от радикально левых до сочиал-демократических, и все это внутри ВЛКСМ упаковывалось. Как, собственно, и в КПСС, где была демократическая платформа, и одновременно в КПСС была Нина Андреева» (интервью № 1).
\end{abstract}

На этой волне комсомольские лидеры, наряду со своей повседневной идеологической работой, занимались организацией ежегодных строительных отрядов, образовательной деятельностью, создавали центры научно-технического творчества молодежи и извлекали из этого прибыль. Поэтому баллотирование представителей комсомольских организаций в депутаты различного уровня, их участие в работе избирательных штабов виделись для большинства вполне органичной траекторией в профессиональной карьере.

Анализ биографий петербургских политтехнологов свидетельствует, что по большей части свой первый политический опыт они получали именно в перестроечный период. Зафиксированы случаи, когда сам политтехнолог, осуществляя свою профессиональную деятельность, параллельно баллотировался в муниципальные или городские органы власти (чаще всего безуспешно), но случалось и так, что политтехнолог, участвуя в избирательной кампании, все же обретал мандат депутата райсовета, например, в 19 лет, достаточно молодом возрасте по меркам политики. Для большинства питерских политтехнологов именно первые выборы в народные депутаты СССР и стали стартом в большой политической карьере. Практически в каждой биографии политтехнологов первой волны (тех, кому сегодня больше 50 лет) их участие в избирательных кампаниях народных депутатов упоминается как важный опыт. По мнению информантов, это был период реального политического процесса и настоящих политических дискуссий.

В биографиях политтехнологов фиксируется довольно ранняя политическая социализация, которая иногда начиналась еще в детстве в кругу семьи или в школе: 
участие в классных политинформациях или же обсуждение новостной программы «Время» были для многих вполне рядовым явлением. Складывалась ситуация, когда интерес к политике сформировался раньше, чем интерес к выборам. В период перестройки часть политтехнологов оказалась в числе главных критиков советского строя и руководящей роли КПСС.

\begin{abstract}
«Ну, можно сказать, со школы был политически активным, и определенные выборы даже в школе в советские времена, можно сказать, были. Я был председателем совета дружины пионерской организации иколь, секретарем комитета комсомола школь, секретарем комитета комсомола курса в военном училище, вступил в КПСС, был кандидатом в члены партии 3 месяиа. Потом, это как раз был 1989 год, тогда я учился в авиационном инженерном училище, я выступил на собрании по поводу всех событий тех времен. Меня за идейные взгляды, несовместимые с членством в партии, исключили из кандидатов и в тот же день исключили из военного училища, и я уехал в Москву. Это было как раз 6 ноября» (интервью № 62).
\end{abstract}

Анализ интервью показывает, что известные в будущем питерские политтехнологи и политики иногда обучались в одних и тех же средних общеобразовательных школах (например, в английских спецшколах советского времени) ${ }^{11}$. Полученные данные демонстрируют, что в некоторых российских регионах прослеживается своя специфика в социально-профессиональном статусе политтехнологов: так, например, доминирование некоторое время назад среди политтехнологов Санкт-Петербурга такой профессиональной группы, как психологи, в первую очередь было связано с открытием в 1989 г. кафедры политической психологии в ЛГУ. Тогда не только преподаватели кафедры, но и студенты психологического факультета активно вовлекались в избирательные кампании города. Немаловажную роль в процессе формирования питерского политтехнологического сообщества сыграл и заведующий кафедрой политической психологии ЛГУ А.И. Юрьев, который начиная с 1980-х гг. осуществлял психологическую подготовку представителей советской номенклатуры, а в 1990-е гг. работал советником председателя Правительства РФ В.С. Черномырдина, мэра Санкт-Петербурга А.А. Собчака и губернатора Санкт-Петербурга В.А. Яковлева.

\footnotetext{
«Юрьев - не политтехнолог, он все-таки идеолог, преподаватель. И в то время, когда он преподавал, политтехнологий как таковых еще не было. Хотя он был первый, кто создал у нас, во-первых, кафедру политпсихологии, а во-вторых, базу для тренировки политиков, тогда он еще коммунистов тренировал в Осиновой роще» (интервью № 6).
}

\footnotetext{
11 Один из политтехнологов в интервью рассказывал, как в свое время принимал в пионеры и повязывал галстук одному петербургскому политику (в настоящее время уже федерального уровня).
} 
Выходцы (особенно первый выпуск) юрьевской школы, имея психологическое образование и опыт ведения избирательных кампаний петербургских политиков, активно рекрутировались в региональные властные структуры и СМИ (редакции журналов, газет, телевидение). Психологическое образование, полученное в СПбГУ, для многих из них стало стартовой площадкой для их последующей политической карьеры. На первых же порах молодая когорта петербургских политтехнологов зачастую работала на волонтерских началах и гораздо позже на профессиональной основе, получая вознаграждение. Свои первые профессиональные кампании политтехнологи Санкт-Петербурга вели «уже почти за деньги».

«По крайней мере, деньги там появлялись, это были выборы народных депутатов РСФСР в областном округе, где на должность виче-премьера шел Яров Юрий Федорович, старый советский работник еще с тех времен, его взяли вице-премьером. Он был депутатом России. Освободился округ, и туда решился избраться очень яркий на тот момент кооперативщик Илья Баскин» (интервью № 6).

Отдельный сегмент в российском политтехнологическом сообществе занимают представители региональной административной власти, которые в выборный период оказываются неизбежно встроенными в этот процесс. Как правило, представители власти выполняют организационные функции политтехнологов, возглавляют избирательный штаб того или иного кандидата, курируют избирательную кампанию в регионе. Особенно часто это случалось на губернаторских выборах, но и после отмены прямых выборов губернаторов использование административного ресурса в избирательных практиках не уменьшилось. Например, в интервью не единожды упоминаются различные формы использования административного ресурса, начиная с регистрации кандидатов и заканчивая торговлей округами взамен на необходимый результат голосования.

«От “Единой России” мы в итоге пошли. Так вот, я должна сказать, что, поскольку кандидат проявил желание и был новым для команды, он вел самостоятельную кампанию, это был единственный округ, в котором он отказался от общего технолога кампании и выбрал личного технолога, я с ним работала. И это было сделано для того, чтобы представители админресурса не смогли перекупить округ и не продать его тем же коммунистам. Мы были вынуждены именно ведением кампании доказывать чистую победу, и они просто не смогли перепродать этот округ представителям админресурса» (интервью № 52).

Для представителей региональной административной власти выполнение функций политтехнолога происходит в период избирательной кампании, когда чиновник, уйдя в отпуск, имеет на это формальное право. При этом региональные чиновники в интервью чаще всего ассоциируют себя не с политтехнологами, a, скорее, с политическими аналитиками. 
«Больше всего мне приходилось выступать в роли аналитика, концептолога либо в формате организаиионной работы, иногда приходилось совмещать эти виды деятельности. Не скажу, что очень часто оказывался в формате финансового куратора. А вот то, что касается выработки концепџии, выбора смысловых параметров, определения рисков, определения того, на какие шаги способны оппоненты, - вот это да. В организационной части это построение структуры штаба, подбор людей в штаб и определение их функиионала. И контроль за соответствием законодательным рамкам, потому что политтехнологи очень часто не учитывают эти ограничения в погоне за результатом. Для меня исходная точка работы - это детальнейшее изучение законодательства, только после этого построение схемы избирательного процесса» (интервью № 70).

Политтехнологическое сообщество, как и любое другое социальное образование, имеет свои различия и иерархии. Как в прошлом, так и сейчас существуют профессиональные рейтинги внутри политтехнологического сообщества. В начале 2000-х гг. цеховым ранжированием занимались сотрудники интернет-портала «Избасс», который был создан в 2003 г. и просуществовал до 2016 г. Анализ данных, представленный «Избасс» в 2015 г., показывает, что в топ-10 «мэтров политконсалтинга» доминировали московские политтехнологи ${ }^{12}$, и лишь двум политтехнологам из Екатеринбурга (А. Бакову и О. Матвейчеву) удалось войти в этот престижный рейтинг. В другой номинации, именуемой «политтехнологи», прочные позиции в 2015 г. занимали 18 москвичей, 6 петербургских профессионалов, 6 екатеринбуржцев. В рейтинге профильных специалистов выделяются такие направления, как юридическое (осуществление правового сопровождения избирательной кампании - 10 персон), организационно-массовое (орговики, руководители агитсети - 10 персон), агитационно-рекламное (пиарщики, медийщики, райтеры - 10 персон) и информационно-аналитическое (социологи, политаналитики и другие - 10 персон). В рейтинге специалистов наблюдается гендерное неравенство: в список из 40 персон вошли лишь 7 женщин, и только 2 женщины в числе 15 «политтехнологов-универсалов», которые способны полностью вести избирательную кампанию.

Другим важным источником информации при анализе внутренних иерархий в профессиональном сообществе является ежегодный рейтинг российских политтехнологов, который формирует «Общая газета» ${ }^{13}$. Анализ рейтингов за период с 2007 по 2020 г. свидетельствует, что существенные трансформации в рейтинге произошли в 2012 г., когда был принят федеральный закон о выборах глав регионов, и в 2016 г., когда рейтинг обрел черты отраслевого. В 2016 г. разработчики рейтинга впервые исключили из него политиков и чиновников, которые никогда не являлись политтехнологами, но имели прямое

\footnotetext{
12 Топ-100 «лучшие политтехнологи (выборщики) России», обновленная версия-2015 // http://www.izbass.ru/odv100top15.htm

13 Ежегодный рейтинг российских политтехнологов (носителей политтехнологической компетентности, тех, кто является специалистом в области формирования общественного мнения, реальными организаторами избирательных и политических кампаний) рассчитывается накануне нового политического сезона и основан на анкетировании экспертов (ТОП-20. Лучшие политтехнологи России-2020 (2020) // Общая газета. 20 января 2020 // https://og.ru/ru/article/109241).
} 
отношение к развитию рынка политических услуг. Если до 2012 г. в рейтинге политтехнологов первые позиции занимали представители федеральной административной элиты либо те, кто осуществлял партийное руководство в «Единой России» (В. Сурков, А. Чесноков, К. Костин, Н. Иванов, В. Володин, Д. Песков, Н. Тимакова, Р. Забиров, С. Железняк и др.), то в более поздний период эти позиции заняли политтехнологи, напрямую аффилированные с федеральной властью. В рейтинги были включены те политтехнологи, которые получали/ получают крупные подряды на выборы, доверенные лица президента России, руководители консалтинговых структур, которые в прошлом либо сейчас обслуживают интересы федеральной и региональных властей. Обращает на себя внимание и тот факт, что при смене руководителя администрации президента произошло персональное обновление в рейтинге политтехнологов, при этом механизм формирования рейтинга с момента его основания в 2007 г. остается неизменным на протяжении 14 лет.

Несмотря на то, что рейтинги российских политтехнологов являются детищем последнего десятилетия, вполне очевидно, что формирование иерархической структуры рассматриваемого профессионального сообщества началось еще в 1990-е гг. По воспоминанию питерского политтехнолога, значимых игроков в политтехнологическом сообществе в начале перестройки было не так много, и основные подряды на крупные избирательные кампании в регионах политические технологи получали всегда из Москвы. В последующие годы произошли лишь закрепление и воспроизводство избирательной системы на зависимых основаниях, частью которой являются множество агентов, в т. ч. политтехнологи.

«В 1990-х там было всего несколько штук <...>, шесть включенных команд, которые занимались “чесом” по России и частично замыкались на Кремль. "Новоком” (Алексея Кошмарова) тоже была одна из таких команд, и надо признать, что эта практика сейчас стала определяющей, все ключевые компании, которые касаются власти, распределяются там, в администрации президента. Это, в общем-то, нормально. Там цуельй кремлевский пул, это, с одной стороны, хорошо, потому что ребята в обойме, а я не... Поэтому я так довольно откровенно говорю, я очень многих из этих людей знаю. Но есть и очень большой недостаток: они абсолютно подневольны, т. е. если кто-то над ними начальник, и чувствует себя очень умным, то они вынуждены соглашаться, даже понимая, что он предлагает глупость; критиковать невозможно» (интервью № 5).

Таким образом, можно утверждать, что значимые позиции внутри сообщества занимает лишь небольшая прослойка политтехнологов первой волны (те, кому сегодня больше 50 лет) либо их ученики. В своем большинстве политтехнологи представляют собой относительно закрытое и немногочисленное сообщество, которое, по оценкам экспертов, составляет не более 200-300 человек по всей России (по другим данным, не более 1000 чел.). Профессиональное сообщество имеет все признаки иерархической структуры, ранжированием которого занимаются представители рынка политических услуг в лице самих политтехнологов либо журналистов. Чаще всего в сообщество политтехнологов 
были рекрутированы руководители комсомольских организаций, журналисты, юристы, психологи, ученые, и в целом оно не представляет собой гомогенного профессионального образования.

\section{Сколько стоит труд политтехнолога и как распределяются заказы}

Избирательные кампании представляют собой многомерный социальный процесс, в который вовлечены различные индивиды и группы, чьи интересы порой не просто не совпадают, а оказываются прямо противоположными. Например, в случае баллотирования кандидатов от провластной и оппозиционной партий победа одних кандидатов является поражением для других и наоборот. При более же детальном рассмотрении становится вполне очевидным, что даже между конкурирующими партиями в ходе избирательных кампаний гораздо больше сходства, чем различий. Это касается не только того, что зачастую одни и те же политтехнологи работают на конкурирующие партии, но и того, что одни и те же кандидаты баллотируются от разных партий и объединений. Например, в избирательной кампании 2016 г. по выборам в парламент Санкт-Петербурга отмечались случаи, когда кандидат одновременно баллотировался от Партии Роста и ЛДПР.

Политтехнологи работают не только в период выборов, но и в межсезонье, консультируя будущих политиков, оказывая консультационные услуги представителям региональной и федеральной власти, причем эти услуги осуществляются на платной основе, хотя так было не всегда. Участники избирательных кампаний вспоминают, что в 1990-х гг. нередки были ситуации, когда консалтинговые услуги кандидатам в депутаты или в губернаторы политтехнологи оказывали бесплатно или за скромный гонорар, но именно те годы стали периодом «золотого кэша», когда деньги со стороны спонсоров кампаний «лились рекой». Молодые и начинающие политтехнологи имели лишь представление о том, как не должно было быть, и поэтому в ход пускались разные доморощенные практики. Один из первых питерских политтехнологов вспоминает, что тогда:

\footnotetext{
«<..> получил пачку плакатов, остаток которых, штук 20, у меня до сих пор лежит. Мне выдали большую банку клея ПВА и отправили по оранжевой ветке метро заклеивать это. Заклеивали мы совериенно чудовищно в те времена: все что есть, мыл клеили. <..> А город тогда выглядел так, что это совершенно не воспринималось как что-то недопустимое. Вот и это был мой первый опыт» (интервью № 7).
}

В начале 2000-х гг. сформировалась важная составляющая рыночного процесса - стоимость произведенного продукта. Все этапы избирательного процесса (начиная с раздачи листовок и заканчивая оплатой труда юриста или имиджмейкера кандидата) обрели стоимостное выражение. Согласно исследованиям РПУ Пермского края, «если на выборах в Законодательное собрание Пермской области 2001 г. кандидаты вложили в свои кампании от 20 до 350 тыс. долларов, то в 2006 г. 
эта цифра выросла до 1 млн долларов. <..> Если избирательная кампания кандидата в депутаты городской думы в марте 2006 г. в среднем стоила 200-250 тыс. долларов, то в Екатеринбурге аналогичная кампания оценивается в 100-150 тыс. долларов. $<\ldots>$ Стоимость избирательной кампании в Законодательное Собрание Пермского края по партийным спискам варьируется от 1 до 5 млн долларов» ${ }^{14}$.

По мнению политолога О.В. Подвинцева, цены на избирательные кампании в современной России в те годы были слишком завышены. По сравнению, например, с американскими избирательными кампаниями, цены на выборах мэра в Пермском крае были выше в среднем в 3 раза. Если выборы в мэры американского города с населением в 2 млн человек имеют стоимостное выражение в 2-3 млн долларов, то, как считает эксперт, аналогичная российская избирательная кампания обходилась кандидату в мэры в 6-9 млн долларов. В целом оценка стоимости избирательных кампаний вне зависимости от уровня организации в современной России носит весьма приблизительный характер. В первую очередь это связано с тем, что в своем большинстве кандидаты в депутаты/мэры/губернаторы часто (вынужденно или осознанно) выступают в роли нарушителя закона об избирательной кампании, когда используют в ходе предвыборной кампании финансовые средства не только из избирательного фонда. Теневой сегмент рынка политических услуг был представлен, как правило, «неучтенкой» и «налом», которые в ходе избирательных кампаний расходовались на издание листовок и баннеров, оплату труда расклейщиков и агитаторов и другие услуги.

«Все зависит от уровня выборов: если выборы местные, вся черная касса - максимум 100 тыс. руб.; если выборы губернаторов (если, например, сейчас взять выборы губернатора в Питере, Беглова), то там уже могут быть миллионы долларов, долларов (!), не рублей. Конечно, фонда еще никакого нет, выборы назначены примерно, избирательный фонд не открыт. Соответственно, все это идет мимо. Можно сколько угодно закачать в фонд, а из фонда оплатить какие-то фиктивныле услуги для кампании и таким образом вывести эти деньги. Тем более выборы - это же интеллектуальные услуги. Мы за 5 миллионов рублей купили консультацию, и как ты докажешь, что эта консультация не была оказана? Ну, то есть, очень много возможностей. Это просто то, что мне в голову приходит, а там сидят люди, которые профессионально этим занимаются» (интервью № 71).

Не менее важной составляющей рынка политических услуг стало формирование социальных сетей, когда был образован круг политтехнологов из числа «своих», между которыми, собственно, и распределялись основные заказы. Как правило, в интервью при описании системы распределения заказов на избирательные кампании политтехнологи использовали такие словосочетания, как «через разные рекомендации», «свои политтехнологи, для того, чтобы делать, то, что нужно делать», «по рекомендации», «по записной книжке», «из моего блокнота». Что касается сложившейся системы распределения основных (крупных) заказов, то можно

14 Современная ситуация на рынке политических технологий Пермского края (2005) // Politictime.ru // http://www.politictime.ru/potis-154-1.html 
утверждать, согласно данным интервью, что главные подряды на ведение избирательных кампаний федерального и регионального уровня в последние годы получают не больше 20 политтехнологов, которые далее по цепочке и рекрутируют региональных политтехнологов, но при этом каждый из них оставляет за собой право по участию/неучастию в выборном процессе. Отказ от работы с тем или иным кандидатом, по мнению опрошенных информантов, случался практически у каждого, но чаще всего это происходило у мэтров политических технологий, которые отчетливо представляют политэкономическую сторону избирательного процесса. По мнению одного из гуру российских политтехнологий, основная причина согласия или отказа от работы с тем или иным кандидатом - финансовая.

\begin{abstract}
«Это единственная причина, я говорю честно и цинично. Кто бы какую причину ни называл, она всегда одна, нет другой причины, все остальное - прикрытие. То есть все эти красивые истории про социильную ответственность, про то, что я никогда не буду с идеологически чуждым элементом работать. <..> Да, к сожалению, это так, а может быть, и к счастью. Кстати, политтехнолог - он вообще должен быть циничным? Ну цииничным, прагматичным? Я знаю костяк этих людей“узок круг этих револючионеров”. Ия не видел более циничной публики. Поэтому мне с ними бесконечно интересно. Что бы они ни говорили, мы понимаем друг друга по гамбургскому счету. То есть они говорят о сочиальной значимости, о культуре, о прочем, я понимаю, что да, М. мало заплатили, и он не хочет брать этот проект, т. е. мы понимаем друг друга с полувзгляда. Всегда решают деньги, я не видел других причин ни у кого» (интервью № 72).
\end{abstract}

Согласно данным интервью, питерские политтехнологи работали по всей стране, иногда участвуя в один сезон одновременно в выборных кампаниях в нескольких регионах и проводя там по два-три месяца ${ }^{15}$. Политтехнологи получали заказы не только на проведение избирательных кампаний, но и принимали участие в строительстве политических партий и объединений, формировании политического имиджа регионов. В 2000-х гг. политтехнологи занимались созданием петербургского отделения «Единой России». В последние годы произошло размывание категории «региональный политтехнолог»: если в прошлом существовали и устойчиво воспроизводились региональные школы московских, питерских, уральских политтехнологов, то в настоящее время одновременно все российские регионы становятся сферой применения профессионального мастерства тех, кто вовлечен в выборный процесс.

«В принциипе, у меня были кампании во многих регионах, были и Мурманская, и Архангельская, и Псковская области. Отдельные проекты были в 40 регионах, а такие автономные большие кампании - это Ленинградская область, Петербург, Москва, Московская область» (интервью № 45).

15 В одном интервью упоминалось, что в высокий политический сезон политтехнолог одновременно вел избирательные кампании в восьми российских регионах. 
Другим агентом на поле избирательных услуг являются профессиональные организации/компании, которые появились в конце 1990-х - начале 2000-х гг. Некоторые из российских политтехнологов стали учредителями консалтинговых компаний, специализирующихся только на предвыборных кампаниях. Так, 11 лет назад один из информантов учредил собственную компанию в Москве и до сих пор активно участвует в избирательных процессах, получая заказы от первой в России PR-компании «Никколо М» ${ }^{16}$ и выступая, по сути, в роли субподрядчика. Этот информант позиционирует свою компанию как профессиональную, не работающую с провластными кандидатами, и которая «никогда не обслуживает российскую власть».

«Нам всегда везло на сложные, конкурентные выборы. Наме преимущество - это ведение настоящих конкурентных кампаний. Есть такие политтехнологи, которые фактически обслуживают те условия, которые им задают, например от той же администрации президента. Это если говорить о выборах губернатора, где есть один единственный победитель сразу, изначально. Мы понимаем, что есть и такое, есть технологи, которые просто обслужсивают эти решения. Мы же всегда работали в рамках сложных электоральных ситуаций» (интервью № 52).

В современной России существует разветвленная сеть российских политтехнологов, но решения о получении крупного подряда, по мнению информантов, принимаются все же в администрации президента. После распределения заказов генеральный подрядчик осуществляет набор региональных субподрядчиков, и часто из этого числа исключаются местные политтехнологи. В этой ситуации избирательные кампании ведут политтехнологи-«варяги», не имеющие регионального происхождения (например, известны случаи, когда подряды на избирательные кампании федерального уровня в Санкт-Петербурге получали не только москвичи, но и новгородцы, и екатеринбуржцы). В этих условиях не знание региональной специфики и профессиональный опыт, а неформальные связи, доверие и взаимные выгоды оказываются ключевыми при выборе подрядчика и субподрядчика.

«По моему мнению, дяденьки 50-60 лет берут себе комплексное ведение регионов, набирают туда за зарплату людей, отправляют и все, потом лишь ведут бюджет. Через администрацию президента разъезжаются по регионам и чувствуют себя неплохо. Из-за этой несправедливой ситуации конкуренция не работает. Может, и мы подрастем и будем в такой же позиции» (интервью № 5).

В целом, если оценивать трансформацию рынка политических услуг в России, то становится очевидным, что сильные изменения произошли именно в 2012 г., после событий на Болотной площади. Количество выборных кампаний резко сократилось, и это сильно отразилось на конкуренции среди политтехноло-

$16 \mathrm{http}: / /$ nikkolom.ru 
гов. Если в прошлом у крупных игроков политического рынка была возможность через систему личных договоренностей осуществлять предвыборные подряды, то за последние 10 лет фактически сформировалась государственная монополия на крупные избирательные кампании (все кампании, которые выше муниципального уровня).

«К. пришел, и он сильно подрезал наш бизнес. Вот этот его пул, который распределяет между собой заказы. Раньше было как? Если я лично веду переговоры, то я могла сама договориться. Сейчас тебе сверху присылают, и все, это сильно подрывает рынок. Так на губернаторский пул выборов, мы знаем, будут распределены заказы только через одного человека из команды К.» (интервью № 52).

Кураторство ключевых избирательных кампаний со стороны федеральных властей в современной России включает в себя не только финансирование кампаний, но и их идеологическое сопровождение, когда для политтехнологов определяют содержание и способы ведения той или иной избирательной кампании: например, федеральная кампания 2018 г. по выбору президента России показала, что в избирательных технологиях креативный подход был совершенно запрещен.

«Федеральная кампания, была установка: не мешать своим креативом. Единственное, что удалось пробить, это опросы на избирательных участках о том, что надо сделать в районах. В районах до сих пор главы отчитываются, они используют эти опросы» (интервью № 5).

Федеральная кампания 2018 г. по выборам президента России стала важным этапом в развитии рынка политических услуг, когда произошел очередной виток по усилению контроля над избирательным процессом со стороны административной элиты. Если в прошлом кураторство выборов осуществляло только одно управление президента по внутренней политике (УВП), то с 2018 г. функции по технологическому обеспечению выборов выполняют сотрудники управления президента по обеспечению деятельности Госсовета (УГС); за медийные процессы отвечает управление президента по общественным процессам (УОП). «Губернатор хочет, чтобы от “Единой России” пошел один кандидат, но есть интересы финансовопромышленных групп в регионе, других структур, а также самих единороссов. Или есть группы в списке "Единой России”, которые нужно объединить по регионам. < ..> УВП [во главе с Яриным] администрирует такие процессы, т. е. является посредником между интересантами. А начальник УГС Харичев участвует в согласовании списков кандидатов на выборах, его управление отвечает за технологов, работу с экспертами, социологию. Кроме того, есть технологический штаб, куда входят представители “Единой России” и обоих управлений - УГС и УВП» ${ }^{17}$.

17 Выборами в Госдуму займутся сразу два управления (2021) // Ведомости. 27 апреля $2021 / /$ https://www.vedomosti.ru/politics/articles/2021/04/27/867915-viborami-gosdumu 
Тотальный контроль последних 20 лет за избирательными кампаниями в регионах со стороны федеральной элиты привел к конфликтам и расколам внутри политтехнологического сообщества; чаще всего линии раскола возникают между представителями молодого и старшего поколений. Молодые политтехнологи оказываются не только в роли исполнителей, но и зачастую в роли критиков генеральных подрядчиков, распределяющих региональные заказы. В участившихся за последние годы провалах кандидатов на региональных избирательных кампаниях «генподрядчик» чаще всего обвиняет молодых политтехнологов, усиливая контроль не только за финансовыми ресурсами выборных кампаний, но и за функционированием профессионального сообщества политтехнологов в целом: «У каждого из региональных поражений есть не только политические имена, но и политтехнологические имена. И вот молодые субподрядчики начали озвучивать эти имена и требовать признать их провалившимися. Акела промахнулся. Отдать Акелу на растерзание. А бюджеты пусть пойдут молодым. Молодость всегда победит. Генподрядчики резонно полагают, что политтехнологии могут превратить $30 \%$ в $55 \%$. А сделать $55 \%$ из 10\% могут только волшебники, да и то, если повезет. И предлагают, что, если кто в сообществе публично критикует непубличную работу коллег, он должен исключаться из профессионального сообщества. А поскольку генподрядчики руководят и профессиональными ассоциациями, и бюджетами от заказчиков, то значит, борзые субподрядчики должны забыть о субподрядах и вспомнить поговорку «волка ноги кормят»»» ${ }^{18}$.

Сложившаяся система кураторства за выборным процессом, порядок распределения крупных заказов, отсутствие политической конкуренции в политическом поле в целом не способствуют развитию выборов как демократического политического института, а оказываются инструментами для формирования новых иерархий и доминирований. Изучение формальных и неформальных аспектов избирательных кампаний в российских регионах показывает, что по своей сути эти кампании представляют двуединый процесс. Границы между политическим бизнесом и политическим процессом стираются, и только время оказывается важным ресурсом: чем больше длится избирательная кампания, тем больше выгоды получат те, кто вовлечен в нее (по некоторым данным, только численность сотрудников избирательных комиссии иногда достигает 1 млн человек) $)^{19}$. В условиях кризисной ситуации не только политики, но и бизнес озадачен подсчетом своих дивидендов. Бизнес находится в таких условиях, когда больше не может «бросаться заказами» и оплачивать дорогостоящие избирательные кампании.

«Как говорит ХХ: “Я противник режима, но всегда работаю на 'Единую Россию”,. Тем более сейчас, когда рынок ужался, такими заказами не бросаются. У него ценник такой, что его прокормить на постоянной основе тяжело, поэтому его привлекают только эпизодически. Раньше у него было много регионов, сейчас его отовсюду подвинули, потому что расходы большие, а результат сомнительный» (интервью № 61).

18 На форуме политтехнологов говорили о профессиональных взаимоотношениях (2018) // Политинформатор.ру. 28 ноября $2018 / /$ https://politinformator.ru/articles/5862

19 Более подробно об этом: Памфилова рассказала, сколько человек работает в избирательной системе // Парламентская газета // https://www.pnp.ru/politics/pamfilova-rasskazala-skolko-chelovek-rabotaet-v-izbiratelnoy-sisteme.html 
И если раньше политтехнологов нанимали, по выражению одного информанта, «на каждый чих» и на все избирательные кампании, то сейчас многие заказчики отчетливо понимают, что политические технологии больше не обладают теми магическими ресурсами, которые могли бы повлиять на исход избирательной гонки. В этой связи, представители бизнеса, которые осознанно дистанцируются от политики, предпочитают вынужденное финансирование выборных кампаний взамен на выживание.

\section{Заключение}

В статье проанализированы одни из главных субъектов избирательного процесса - представители федерального и регионального политтехнологического сообщества. Эмпирические данные позволили реконструировать историю политтехнологического сообщества, практики рекрутирования, этапы институционализации профессиональной общности, ее статусные характеристики, определить специфику ведения избирательных кампаний в российских регионах, также были рассмотрены экономические аспекты избирательных кампаний в российских регионах.

Проведенный анализ показал, что процесс институционализации политтехнологического сообщества носит незавершенный характер, и это связано не только с тем, что происходит внутри профессионального сообщества, но и с продолжающейся трансформацией политических институтов. Особенностью институционализации профессии политтехнологов является то, что в эту профессию в условиях опережения спроса над предложением в начале зарождения рынка политических услуг мог попасть любой человек. В биографических интервью зафиксировано, что политтехнологиями активно занимались представители различных профессиональных групп, зачастую вовсе не связанные с политикой. В целом же карьерные траектории региональных политтехнологов оказываются тесно взаимосвязанными с их «большим начальником», в роли которого могут выступать главы районов, муниципалитетов, руководители правительственных структур, региональных СМИ, бизнес-структур ${ }^{20}$. Участие политтехнологов в избирательных кампаниях политических партий, которые активно используют государственные ресурсы, неизбежно влияет на характер труда представителей политтехнологического сообщества. Это проявляется не только в распределении заказов на выборные кампании в зависимости от заказчика и выполнении договоренностей на «подневольных условиях», но и в отсутствии профессиональной конкуренции внутри сообщества.

В работе определено, что впервые политтехнологи в России появились в 1990-е гг., и с этого периода ни одна предвыборная кампания без них не обходилась. Не только в мегаполисах, но и на региональном уровне компании политического консалтинга активно боролись за место под солнцем на формирующемся, молодом рынке политических услуг. В 2002 г. стартовал новый этап в развитии

20 Отдельный сегмент российского политтехнологического сообщества представляет пул штатных партийных политтехнологов и сотрудников крупных кампаний, которые обеспечивают администрирование избирательных кампаний в регионах присутствия бизнес-структуры. Анализ этих сегментов не входил в задачи данного исследования. 
рынка политических услуг, когда были введены законодательные ограничения по применению определенных политтехнологий, и профессиональная деятельность политтехнологов начала регулироваться согласно правовым нововведениям.

Опираясь на исследования системы распределения крупных заказов (по аналогии с крупным российским бизнесом), можно утверждать, что чаще всего участие в избирательных кампаниях зависит от позиции политтехнолога в прокремлевском рейтинге. По данным интервью, главные подряды на ведение избирательных кампаний федерального и регионального уровней получают не больше 20 политтехнологов, которые далее по цепочке рекрутируют региональных политтехнологов. Выявлено, что внутри политтехнологического сообщества происходят множественные конфликты. Это приводит к тому, что молодое поколение политтехнологического сообщества оказывается не только в роли исполнителя воли власти, но и часто в роли оппонентов главных подрядчиков на выполнение избирательных кампаний в региональной России.

За последние годы процесс подготовки к выборам и осуществление самой избирательной кампании приобретают все более затяжной характер, когда затраты кандидатов, доходы агентов рынка политических услуг и время выступают в роли взаимозависимых величин. Подготовку к выборным кампаниям представители региональных властей, как правило, осуществляют задолго до начала самих выборов, используя при этом имеющиеся у них неограниченные административные ресурсы. При этом не стоит абсолютизировать роль административного ресурса в период проведения региональных избирательных кампаний. Материалы интервью демонстрируют, что в условиях нарастания протестных настроений среди россиян, в т. ч. в среде бюджетников, массово рекрутированных в работу избирательных комиссий, формируется критическая прослойка, которая отказывается от участия в фальсификации выборных результатов либо осуществляет это за отдельную оплату.

\section{Литература}

Барсукова С.Ю., Денисова-Шмидт Е.В. (2020) «Политические инвестиции» бизнеса в России, или почему бизнес финансирует избирательные кампании // ПОЛИС. № 3. C. $110-125$.

Барсукова С.Ю., Звягинцев В.И. (2006) Механизм «политического инвестирования», или как и зачем бизнес участвует в выборах и оплачивает партийную жизнь // ПОЛИС. № 2. C. 110-121.

Барсукова С.Ю., Левин С.Н. (2020) Соотношение административного и финансового ресурсов в ходе избирательных кампаний в современной России: региональная специфика // Мониторинг общественного мнения: экономические и социальные перемены. № 4. C. 41-59.

Голосов Г.В. (1999) Партийные системы России и стран Восточной Европы: генезис, структуры, динамика. М.: Весь Мир.

Гусев Д., Матвейчев О., Хазеев Р., Чернаков С. (2006) Уши машут ослом. Современное социальное программирование. Пермь: Студия Зебра.

Киселев К. (2002) От «идейного шаманства» к идеологии профессионализма // Советник. № 4. C. 4-7.

May В., Кочеткова О., Жаворонков С. (2019) Экономические факторы электорального поведения (опыт России 1995-1996 годов) // Институт экономической политики им. Е.Т. Гайдара // https://www.iep.ru/files/text/usaid/23-new.pdf 
Морозов О.В., Заславский С.Е., Чихарев И.А., Столетов О.В., Тюков Н.А., Полулях Д.С. (2017) Формирование модели политического образования в условиях трансформации рынка политических профессий. Аналитический доклад. М.

Попова O.В. (2011) Политические установки петербуржцев перед новым электоральным циклом // Вестник СПбГУ. Серия 6: Философия. Культурология. Политология. Право. Международные отношения. № 1. С. 67-75.

Попова О.В. (2012) Рейтинги как элемент информационной политики в электоральном цикле // Политическая наука. № 1. С. 81-93.

Учеба под выборы: зачем «Единая Россия» создает Высшую партийную школу (2018) // РБК. 5 декабря 2018 // https://www.rbc.ru/politics/05/12/2018/5c068b9c9a794727d3964790

Хлопин А. (1997) Становление гражданского общества в России: институциональная перспектива // Pro et Contra. T. 2. № 4. С. 60-76.

Хьюз Э. (1965) Исследование занятий // Социология сегодня: Проблемы и перспективы. М.: Прогресс. С. 493-515.

Alesina A., Roubini N., Cohen G.D. (1997) Political Cycles and the Macroeconomy, Cambridge, MA and London: The MIT Press.

Gandhi J. (2008) Political Institutions under Dictatorship, New York: Cambridge University Press.

Levitsky S., Way L. (2010) Competitive Authoritarianism after the Cold War, Cambridge: Cambridge University Press.

Magaloni B. (2010) The Game of Electoral Fraud and the Ousting of Authoritarian Rule // American Journal of Political Science, vol. 54, no 3, pp. 751-765.

Nordhaus W. (1975) The Political Business Cycle // Review of Economic Studies, vol. 42, no 2, pp. 169-190.

Schedler A. (ed.) (2006) Electoral Authoritarianism: The Dynamics of Unfree Competition, Boulder, CO: Lynne Rienner.

Way L. (2005) Authoritarian State Building and the Sources of Regime Competitiveness in the Fourth Wave: The Cases of Belarus, Moldova, Russia, and Ukraine // World Politics, vol. 57, no 2, pp. 231-261.

Wilson K. (2012) How Russians View Electoral Fairness: A Qualitative Analysis // Europe-Asia Studies, vol. 64, no 1, pp. 145-168.

\title{
"I Oppose the Regime but I Always Work for "Yedinaya Rossiya": on the Community of Political Strategists in Modern Russia
}

\author{
N. KOLESNIK*
}

\begin{abstract}
*Natalya Kolesnik - PhD in Sociology, Academic Secretary, Senior Researcher, Sector of Sociology of Government and Civil Society, Sociological Institute of the Russian Academy of Sciences - Branch of the Federal Center of Theoretical and Applied Sociology of the Russian Academy of Sciences. Address: 25/14 7th Krasnoarmejskaya St., Saint Petersburg, 190005, Russian Federation. E-mail: n.kolesnik@socinst.ru
\end{abstract}

Citation: Kolesnik N. (2021) "I Oppose the Regime but I Always Work for 'Yedinaya Rossiya"": on the Community of Political Strategists in Modern Russia. Mir Rossii, vol. 30, no 4, pp. 79-105 (in Russian). DOI: 10.17323/1811-038X-2021-30-4-79-105 


\begin{abstract}
This article examines institutionalization in the market for political services. In particular, special attention is drawn to political strategists. First, the author reviews academic discussions around the relationship between authoritarian regimes and electoral processes. Among the important characteristics of "electoral autocracies" the following are highlighted: the presence of a multi-party system, regular parliamentary elections, universal suffrage and other important components of the democratic landscape. The empirical part clarifies the political and economic aspects of election campaigns in the Russian regions. To that purpose, 76 in-depth semi-structured interviews with the main agents of the electoral process in the Russian regions were conducted (ranging from political strategists to a representative of a regional administration). The study covers several main aspects: the formation of the market for political professions in modern Russia; sources of recruitment; the socio-economic status of political strategists; and the features of post-career professional trajectories. The analysis reveals that the formation of a community of political strategists in modern Russia is not yet complete, and election campaigns are a two-pronged process where the boundaries between political business and political process are blurred and the main aspect is not the quality of the provided services but the durability of the process itself.
\end{abstract}

Keywords: election campaign, elections, political strategists, market, Russian region, power, resources

\title{
References
}

Alesina A., Roubini N., Cohen G.D. (1997) Political Cycles and the Macroeconomy, Cambridge, MA and London: The MIT Press.

Barsukova S.Yu., Denisova-Schmidt E.V. (2020) «Politicheskiye investitsii» biznesa v Rossii, ili pochemu biznes finansiruyet izbiratel'nyye kampanii ["Political Investment" of Business in Russia, or Why Business Finances Election Campaigns]. POLIS, no 3, pp. 110-125.

Barsukova S. Yu., Levin S. N. (2020) Sootnosheniye administrativnogo i finansovogo resursov v khode izbiratel'nykh kampaniy $\mathrm{v}$ sovremennoy Rossii: regional'naya spetsifika [The Ratio of Administrative and Financial Resources during Election Campaigns in Modern Russia: Regional Specifics]. Monitoring obshchestvennogo mneniya: ekonomicheskiye $i$ sotsial'nyye peremeny, no 4, pp. 41- 59.

Barsukova S.Yu., Zvyagintsev V.I. (2006) Mekhanizm «politicheskogo investirovaniya», ili kak i zachem biznes uchastvuyet $\mathrm{v}$ vyborakh i oplachivayet partiynuyu zhizn [The Mechanism of "Political Investment", or What and Why Business Participates in the Elections and Pays for Party Life]. POLIS, no 2, pp. 110-121.

Gandhi J. (2008) Political Institutions under Dictatorship, New York: Cambridge University Press. Golosov G.V. (1999) Partiynyye sistemy Rossii i stran Vostochnoy Evropy: genezis, struktury, dinamika. [Party Systems of Russia and Eastern-European Countries: Genesis, Structures, Dynamics], Moscow: Ves' Mir.

Gusev D., Matveychev O., Khazeyev R., Chernakov S. (2006) Ushi mashut oslom. Sovremennoe sotsial'noye programmirovaniye [Ears Waving a Donkey. Modern Social Programming], Perm: Studio Zebra. 
Hughes E. (1965) Issledovanie zanyatiy [Study of Classes]. Sotsiologiya segodnya: problemy $i$ perspektivy [Sociology Today: Problems and Prospects], Moscow: Progress, pp. 493-515.

Khlopin A. (1997) Stanovlenie grazhdanskogo obshchestva v Rossii: institutsional'naya perspektiva [Formation of Civil Society in Russia: Institutional Perspective]. Pro et Contra, vol. 2, no 4, pp. 60-76.

Kiselev K. (2002) "Ot ideinigo shamanstva k ideologii professionalizma [From Ideological Shamanism to the Ideology of Professionalism]. Sovetnik, no 4, pp. 4-7.

Levitsky S., Way L. (2010) Competitive Authoritarianism after the Cold War, Cambridge: Cambridge University Press.

Magaloni B. (2010) The Game of Electoral Fraud and the Ousting of Authoritarian Rule. American Journal of Political Science, vol. 54, no 3, pp. 751-765.

Mau V., Kochetkova O., Zhavoronkov S. (2019) Ekonomicheskiye faktory elektoral'nogo povedeniya (opyt Rossii 1995-1996 godov) [Economic Factors of Electoral Behavior (Experience of Russia 1995-1996)]. Gaidar Institute for Economic Policy. Available at: https://www.iep.ru/files/text/usaid/23-new.pdf, accessed 25.05. 2021.

Morozov O.V., Zaslavskiy S.Ye., Chikharev I.A., Stoletov O.V., Tyukov N.A., Polulyakh D.S. (2017) Formirovaniye modeli politicheskogo obrazovaniya v usloviyakh transformatsii rynka politicheskikh professiy [Formation of a Model of Political Education in the Context of Transforming the Market of Political Professions]. Analytical report, Moscow.

Nordhaus W. (1975) The Political Business Cycle. Review of Economic Studies, vol. 42, no 2, pp. 169-190.

Popova O.V. (2011) Politicheskiye ustanovki peterburzhtsev pered novym elektoral'nym tsiklom [Political Attitudes of Petersburgers in Front of the New Electoral Cycle]. Vestnik SPbGU, Seriya 6, no 1, pp. 67-75.

Popova O.V. (2012) Reytingi kak element informatsionnoy politiki v elektoral'nom tsikle [Ratings as an Element of Information Policy in an Electoral Cycle]. Politicheskaya nauka, no 1, pp. 81-93.

Schedler A. (ed.) (2006) Electoral Authoritarianism: The Dynamics of Unfree Competition, Boulder, CO: Lynne Rienner.

Ucheba pod vybory: zachem «Yedinaya Rossiya» sozdayet Vysshuyu partiynuyu shkolu (2018) [Education for the Election: Why "United Russia" Creates the Highest Party School]. $R B K$, December 5, 2018. Available at: https://www.rbc.ru/politics/05/12/2018/5c068b9c9a794727d3964790, accessed 25.05. 2021.

Way L. (2005) Authoritarian State Building and the Sources of Regime Competitiveness in the Fourth Wave: The Cases of Belarus, Moldova, Russia, and Ukraine. World Politics, vol. 57, no 2, pp. 231-261.

Wilson K. (2012) How Russians View Electoral Fairness: A Qualitative Analysis. Europe-Asia Studies, vol. 64, no 1, pp. 145-168. 